\title{
Methamphetamine Exposure During the First, but Not the Second Half of Prenatal Development, Affects Social Play Behavior
}

\author{
Mária ŠEVČÍKOVÁ ${ }^{1}$, Ivana PETRÍKOVÁ ${ }^{1}$, Romana ŠLAMBEROVÁ ${ }^{1}$ \\ ${ }^{1}$ Charles University, Third Faculty of Medicine, Department of Physiology, Prague, Czech Republic
}

Received June 10, 2019

Accepted December 10, 2019

Epub Ahead of Print March 23, 2020

\section{Summary}

Methamphetamine (MA), as a psychostimulant drug that crosses the placental barrier, may disrupt the development of social play. The present study aims to examine the effect of prenatal MA (5 mg/kg) exposure during the first (gestational day (GD) 1-11) or second (GD 12-22) halves of prenatal development of rats on social play behavior. To investigate an acute effect of MA on social play in adulthood, juvenile rats were exposed to a dose of $1 \mathrm{mg} / \mathrm{kg}$ MA or saline on the test day and tested for social play for $15 \mathrm{~min}$. Prenatal exposure to MA during GD 1-11 increased social play behavior during 5-10 min interval of the test in males but not females. Prenatal MA during GD 12-22 did not influence social play in males nor females. However, social play occurred to a greater extent in GD 12-22 groups compared with GD 1-11. Acute exposure to MA eliminated playful behavior in all groups and decreased social exploration in GD 1-11. Our results suggest that manipulation of prenatal development during the first half of the gestational period has a greater impact on social play behavior than during the second half.
\end{abstract}

\section{Key words}

Psychostimulants - Methamphetamine - Social play behavior Prenatal development $\bullet$ Sensitization

\section{Corresponding author}

Romana Šlamberová, Department of Physiology, Third Faculty of Medicine, Ke Karlovu 4, 12000 Prague, Czech Republic. E-mail: romana.slamberova@lf3.cuni.cz

\section{Introduction}

An essential part of the development, which is seen in all mammalian species, involves a characteristic form of rough-and-tumble play known as social play behavior (Panksepp et al. 1984, Rubin et al. 1978, Špinka et al. 2001). It is the earliest form of social behavior directed toward peers and not the mother (Pellis and Pellis 1998, Vanderschuren et al. 1997). Social isolation during the time when social play reaches its peak leads to long-lasting disturbances in emotional, social, and cognitive skills (Van den Berg et al. 1999, Vanderschuren and Trezza 2014). Neurodevelopmental disorders show similar behavioral abnormalities (Jordan 2003, Nijhof et al. 2018, Ryan et al. 2018). Social play is modulated by neurotransmitter systems involved in reward and motivation circuits and is as highly sought as food, sex, and drugs of abuse, which makes social play a natural reinforcer (Douglas et al. 2004, Siviy and Panksepp 2011, Vanderschuren et al. 1997).

A euphoric state, increased energy, and heightened vigilance are induced not only by social play but also by amphetamines, which are synthetic psychostimulant drugs. These effects are mediated by increasing the synaptic concentration of the neurotransmitters dopamine (DA), noradrenaline (NA), and to a lesser extent serotonin (5-HT), by stimulating their release and inhibiting their reuptake (Rothman and Baumann 2003, Rothman et al. 2001, Sulzer et al. 1995). Psychostimulants such as methylphenidate, amphetamine, and cocaine have been shown to suppress social play (Siviy and Panksepp 2011, Trezza et al. 2010). It seems that the effect of cocaine is mediated, in part, through dopaminergic neurotransmission, whereas the effects of amphetamine and methylphenidate are mediated through NA (Achterberg et al. 2014, Trezza et al. 2010, Vanderschuren et al. 2008). DA plays an important role 
in motivating social play, whereas NA influences its emotional and cognitive aspects. However, the effect of methamphetamine (MA) on social play behavior has not been addressed in the literature, and there is a lack of research on the prenatal effects of psychostimulants on social play behavior.

The research of our laboratory is focused on the prenatal effect of MA. Due to its lipophilic character, MA crosses the placenta when abused during pregnancy (Burchfield et al. 1991, Dattel 1990) and enters breast milk during lactation (Rambousek et al. 2014). These represent mechanisms by which MA can impair both the prenatal and postnatal development of the fetus. Our recent studies have shown that prenatal exposure to MA impairs postnatal sensorimotor development of rat pups (Malinová-Ševčíková et al. 2014, Šlamberová et al. 2006). Furthermore, the adverse effects of MA can affect the second generation of rats, which were not exposed to MA (Šlamberová et al. 2007). Prenatal exposure to MA impairs cognition (Hrebíčková et al. 2016, Macúchová et al. 2017, Šlamberová et al. 2014), affects the stress response (Holubová et al. 2017), anxiety (Macúchová et al. 2016), and pain sensitivity later in life (Yamamotová et al. 2011). The exposure to MA during prenatal development may sensitizes rats to the same or various drugs in adulthood (Macúchová and Šlamberová 2017). The present study is the first of our studies to examine the effect of MA on social play behavior of juvenile rats. However, in our previous studies, rats prenatally or neonatally exposed to various psychostimulants were observed as adults to assess their social interactions (social interaction test SIT). The studies demonstrated that psychostimulants, such as MA, amphetamine, cocaine, and 3,4-methylenedioxymethapmhetamine (MDMA) suppress social interaction in adult male rats in a dose-specific manner (ک̌lamberová et al. 2015a, Šlamberová et al. 2010). Social interactions in adulthood were decreased in rats prenatally exposed to MA in the same periods like the present study (Hrebíčková et al. 2017). Therefore, we hypothesized that MA would also cause changes in social play behavior during adolescence.

In line with our previous research (Hrebíčková et al. 2014, Hrebíčková et al. 2017, Hrebíčková et al. 2016, Malinová-Ševčíková et al. 2014, Ševčíková et al. 2017), the present study continues to examine the effects of MA during different developmental stages, i.e., the first or second half of gestation. It has been shown that different brain structures mature during different developmental stages (Bayer et al. 1993). Neurulation, a process that occurs early in embryogenesis, is completed by approximately gestational day (GD) 11 (Rice and Barone 2000). Moreover, teratogenic insults are more likely to occur during early organogenesis, which in rats is between GD 7-12 (Schmidt and Johnson 1997). Regional development of the brain continues into the postnatal period. The prefrontal cortex, which plays a key role in the cognitive part of social play behavior, develops from GD 12 to postnatal day (PD) 20 (Kolb et al. 2012). The neurons of the mesocorticolimbic DA system, which are the structural base for the emotional processes of social play, are seen, for the first time, on GD 13 (Rice and Barone 2000). Neurons of the noradrenergic system, which are assumed to be involved in the arousal response, attention, anxiety, and learning and memory (Herlenius and Lagercrantz 2004), appear between GD 12-14 (Sundstrom et al. 1993). MA would seem to have the potential to influence those brain regions that are developing at the time of drug exposure.

Based on the previous findings, the present study aimed to investigate whether the frequency and duration of social play behavior elements changed in response to prenatal MA exposure. Second, we investigated the acute effect of MA exposure in adolescence on social play behavior. We hypothesized that MA would have an adverse effect on the offspring in both the early and late prenatal exposure groups. However, we expected the effects of MA during the first half of prenatal development, based on the demanding processes of embryogenesis, to have a greater effect. Moreover, an acute dose of MA was also expected to impair social play behavior.

\section{Materials and Methods}

\section{Prenatal animal care and prenatal drug treatment}

Adult albino Wistar rats, raised by Charles River Laboratories International, Inc. and delivered by Velaz (Prague, Czech Republic) were used. Males (300-350 g) were housed 4 per cage and females (250-300 g) were housed 5 per cage. Rats were kept in a temperaturecontrolled $\left(22-24^{\circ} \mathrm{C}\right)$ colony room, on a $12: 12 \mathrm{~h}$ light: dark cycle with lights on from $0600 \mathrm{~h}$, with free access to food and water. After one week of acclimation, females were smeared (vaginal lavage) to determine their phase of the estrous cycle. At the onset of the estrous phase, one female and one male were housed overnight. The next morning females were smeared again for the presence of 
sperm and that day was counted as the first day of gestation (GD 1). Females were randomly assigned to those, who would receive MA or saline (SA) during GD 1-11 and those, who would receive MA or SA during GD 12-22. For 11 days of gravidity, mothers were subcutaneously injected (s.c.) with MA at $5 \mathrm{mg} / \mathrm{kg} / \mathrm{day}$ (volume $1 \mathrm{ml} / \mathrm{kg} /$ day). A dose of $5 \mathrm{mg} / \mathrm{kg}$ of MA has been shown to induce comparable fetal brain drug concentrations and similar behavioral changes to those found in humans (Acuff-Smith et al. 1992). SA females were injected with s.c. saline at the same time and the same volume $(1 \mathrm{ml} / \mathrm{kg} /$ day $)$ as the MA group. The day of delivery was designated as PD 0 . Mothers and their litters were left undisturbed in their cage on that day.

\section{Litter characteristics}

On PD 1, pups born on the same day were crossfostered, and litter size was adjusted to 14 . Whenever possible, the same numbers of MA and SA-exposed pups, as well as male and female pups, were kept in each litter. For identification, the pups were tattooed on the left or right leg to indicate prenatal MA or SA exposure, respectively. On PD 21, the pups were weaned and split into two cages according to sex. Pups were left in these cages until PD 28.

\section{Social play behavior and acute drug treatment}

Behavioral procedures of social play used in the present study were mostly reproduced according to studies by Vanderschuren, Achtenberg, and Trezza (e.g., Achterberg et al. 2014, Trezza et al. 2009a, Vanderschuren et al. 2008). Two weeks before testing, the light-dark cycle was reversed in the colony room (lights on for $12 \mathrm{~h}$, from $1800 \mathrm{~h}$ ). The experiments were performed in a plexiglas cage measuring $43 \times 26.5 \times 18 \mathrm{~cm}$ $(1 \times \mathrm{W} \times \mathrm{h})$, with wood shavings covering the floor, in a room under dim light conditions. On PD 28 and 29, each animal was individually habituated to the test cage for $10 \mathrm{~min}$. To facilitate the expression of social play behavior during testing, rats were socially isolated the whole night before testing (approximately 16 hours). On the test day, PD 30, pairs of rats were exposed to an acute dose of MA $(1 \mathrm{mg} / \mathrm{kg})$ or $\mathrm{SA}$ at the same volume $(1 \mathrm{ml} / \mathrm{kg}) 45 \mathrm{~min}$ before testing. The plasma and brain concentrations, at a dose of $1 \mathrm{mg} / \mathrm{kg}$ of MA, have been shown to peak 45-60 min after exposure (Rambousek et al. 2014). According to our preliminary and published data (Schutová et al. 2010), a $1 \mathrm{mg} / \mathrm{kg}$ dose of MA does not induce stereotypical behavior in control adult rats.
For the test, two rats with the same gestation exposure period, sex, prenatal, and acute drug exposure were placed into the test cage and recorded for $15 \mathrm{~min}$. One pair of rats were considered as one unit. To reduce the influence of dominance, rats were paired with other rats with a very similar body weight and with rats that were not cage mates. A video camera was used for recording, and the recordings were analyzed later. The recordings were examined using the ODLog (Macropod Software) program. The frequency of pinning (i.e., one of the animals laying in supine position on the floor with the other animal standing over it, which serves as a social releaser of a continuing play round) and the frequency of pouncing (i.e., one of animals soliciting the partner by attempting to nose or rub the nape of its neck) were scored as elements of social play behavior. Pinning and pouncing are considered to be the major elements for social play behavior in rats, because they are simulated by social isolation and alternate with other playful elements such as boxing or following (Vanderschuren et al. 2016, 1997). Also, the overall duration of social play behavior (i.e., pinning, pouncing, boxing struggling using the forepaws in vertical position) was measured as well as the duration of non-playful forms of social interactions (i.e., climbing over the partner, sniffing or grooming the partner). The rest of the $15 \mathrm{~min}$, during which rats did not play or explorate each other, represent other activities, such as space exploration (sniffing, rearing, and manipulating shavings), selfgrooming or freezing. Other activities were not measured, since they do not refer to social play behavior (Vanderschuren et al. 1997). For a more detailed explanation of the social play behavior elements see the studies by Vanderschuren et al. (1997), Trezza et al. (2009a), Achterberg et al. (2014).

\section{Statistical analysis of social play behavior}

Eight pairs of pups were used in each group. Frequencies of pinning and pouncing, total play duration, and duration of social exploration were calculated per pair and expressed as a mean \pm SEM. To determine whether the prenatal and acute effects of MA on social play behavior changed over time, the 15-min test session was divided into three 5-min intervals, which were analyzed using a three-way ANOVA with repeated measures (prenatal drug $\times$ acute drug $\times$ time). A oneway ANOVA (acute drug) was used to analyze the single acute effect of MA. To assess the differences among the prenatal exposure periods, a one-way ANOVA (exposure 
period) was used. Analyses were followed by the Fisher's LSD post-hoc test where appropriate. Differences were considered significant if $p<0.05$. STATISTICA software was used for statistical analyses.

\section{Results}

For a clearer illustration of overall rats behavior, proportion of social play duration, social exploration, and other non-social activities during $15 \mathrm{~min}$ of the social play test is displayed in Figure 1. Play duration includes pouncing, pinning and boxing. Social exploration represents sniffing and grooming the partner or climbing over the partner. Other activities include space exploration (sniffing, rearing, and manipulating shavings), self-grooming or freezing.

Effect of prenatal and acute MA exposure on social play behavior

To determine whether the effects of prenatal MA on social play behavior changed over time, the 15-min test session was divided into three 5-min intervals. The three-way ANOVA with repeated measures (prenatal drug $\times$ acute drug $\times$ time) revealed differences in a group of males of GD $1-11$ exposure period. Pinning $[\mathrm{F}(2,56)=6.05, \mathrm{p}=0.004 * *] \quad$ (Fig. 2A) and pouncing $\left[\mathrm{F}(2,56)=5.26, \mathrm{p}=0.008^{* *}\right]$ (Fig. $2 \mathrm{~B}$ ) increased during the middle time interval (i.e., 5-10 min) in males prenatally but not acutely exposed to MA. Total play duration increased during the middle time interval but decreased during the last time interval (i.e., $10-15 \mathrm{~min}$ ) of the test $[\mathrm{F}(2,56)=9.07, \mathrm{p}=0.0004 * * *]$ (Fig. 2C). The exposure to prenatal MA did not affect social exploration in any of the intervals $[\mathrm{F}(2,56)=1.34, \mathrm{p}=0.27]$ (Fig. 2D). The effect of acute MA was significant in pinning, pouncing and total play duration and is mentioned in the paragraph below. There were no significant effects in social play behavior for other groups, i.e., females of GD 1-11 exposure period, males and females of GD 12-22 exposure period. The results are as follows: group of females of GD 1-11 exposure period - pinning $[\mathrm{F}(2,56)=0.80, \mathrm{p}=0.46]$, pouncing $[\mathrm{F}(2,56)=0.71$, $\mathrm{p}=0.49]$, total play duration $[\mathrm{F}(2,56)=0.21, \mathrm{p}=0.81]$, and social exploration $[\mathrm{F}(2,56)=0.15, \mathrm{p}=0.86]$, males of GD 12-22 exposure period - pinning $[F(2,56)=0.002$, $\mathrm{p}=0.99]$, pouncing $[\mathrm{F}(2,56)=0.33, \mathrm{p}=0.72]$, total play duration $[\mathrm{F}(2,56)=0.75, \mathrm{p}=0.48]$, and social exploration $[F(2,56)=1.96, p=0.15]$, females of GD 12-22 exposure period - pinning $[\mathrm{F}(2,56)=0.50, \mathrm{p}=0.61]$, pouncing $[\mathrm{F}(2,56)=1.47, \mathrm{p}=0.24]$, total play duration $[\mathrm{F}(2$, $56)=2.21, \mathrm{p}=0.12]$, and social exploration $[\mathrm{F}(2,56)=2.45$, $\mathrm{p}=0.09]$. For the statistical analyses, groups of males and females were used separately.

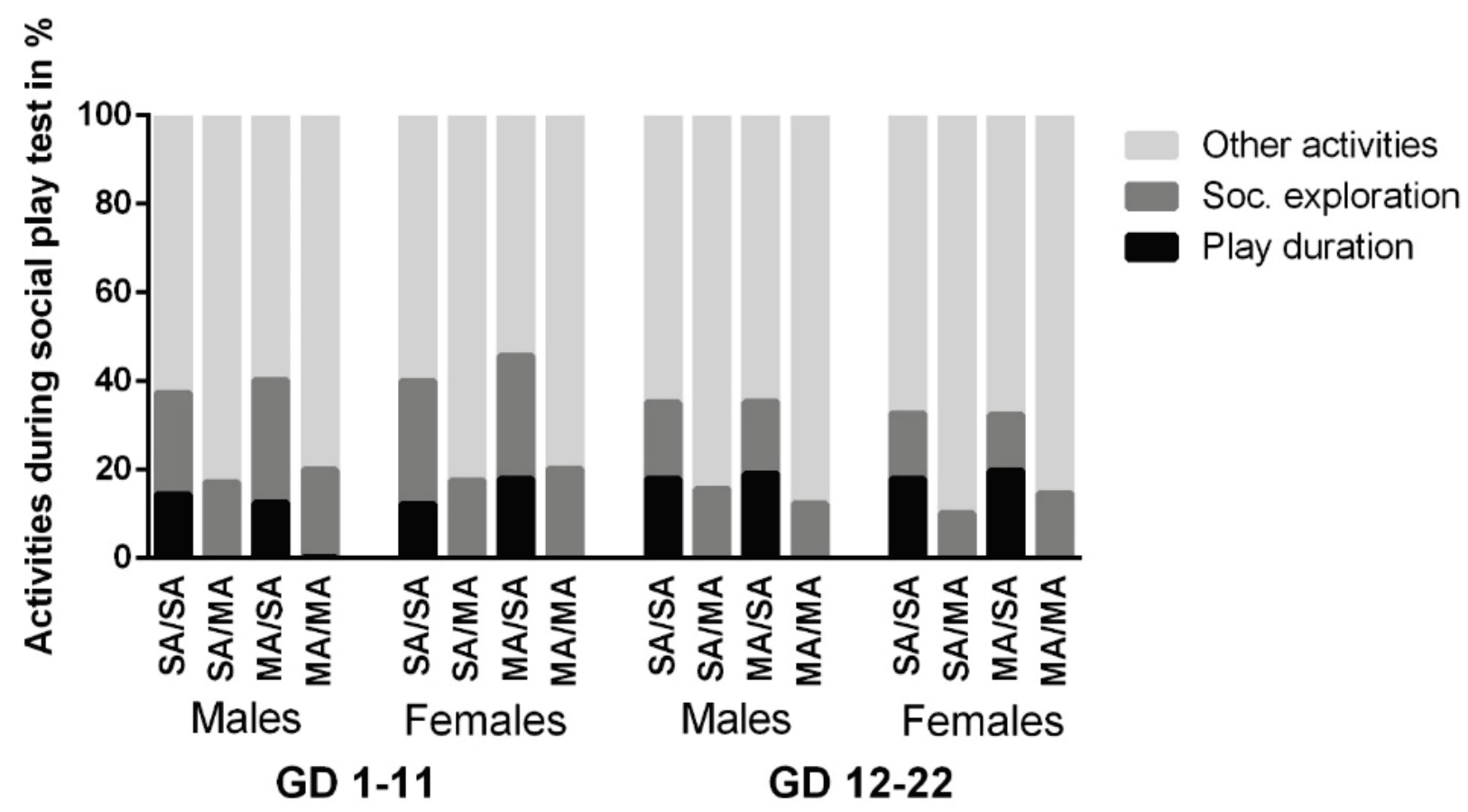

Fig. 1. Proportion of activities during $15 \mathrm{~min}$ of social play test in percentage. Play duration includes pouncing, pinning and wrestling. Social exploration is the time of sniffing and grooming the partner or climbing over the partner. Other activities include space exploration (sniffing, rearing, and manipulating shavings), self-grooming or freezing. Groups are denoted as prenatal exposure/acute exposure. SA - saline exposure, MA - methamphetamine exposure, GD - gestational day. 

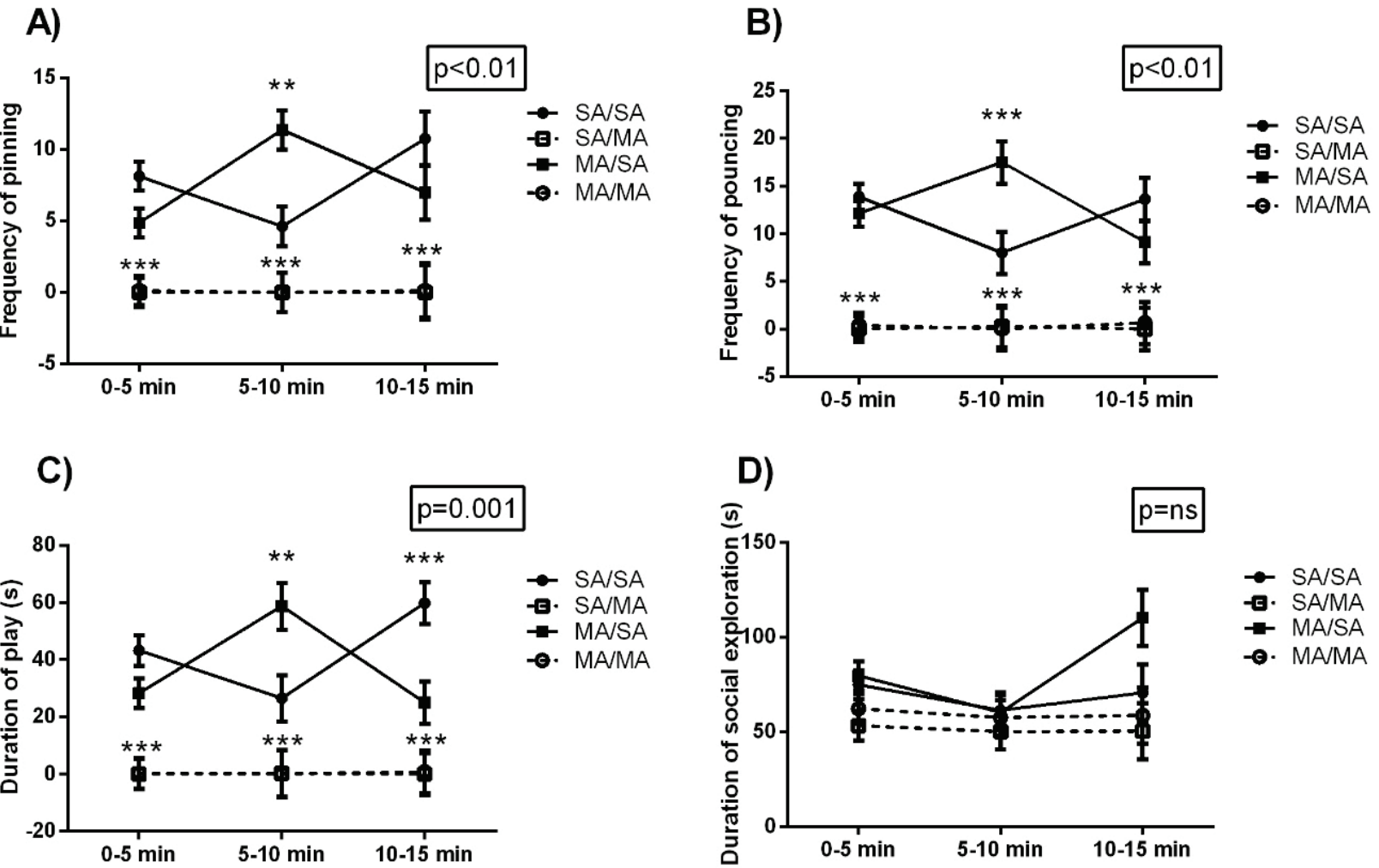

Fig. 2. Effect of prenatal and acute $M A$ exposure on the change of social play behavior in the group of males GD 1-11 over time, during three intervals (0-5 min, 5-10 min, 10-15 min). (A) The frequency of pinning, (B) The frequency of pouncing, (C) Total play duration, (D) Duration of social exploration. Values are means \pm SEM $(n=8)$. The three-way ANOVA with repeated measures (prenatal drug $\times$ acute drug $\times$ time) was used for statistical analyze. The main effect is given in box, asterisks represents the differences with the SA/SA group revealed by post-hoc test. Groups are denoted as prenatal exposure/acute exposure. SA - saline exposure, MA methamphetamine exposure, GD - gestational day.
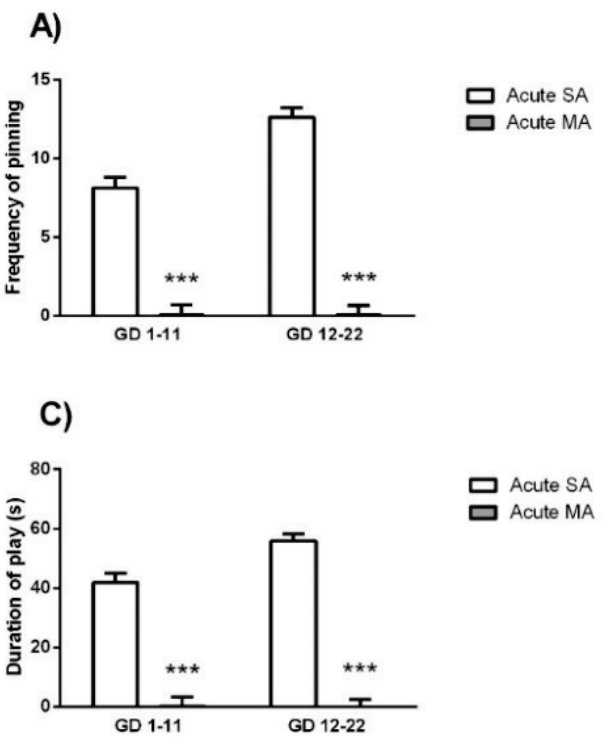

B)

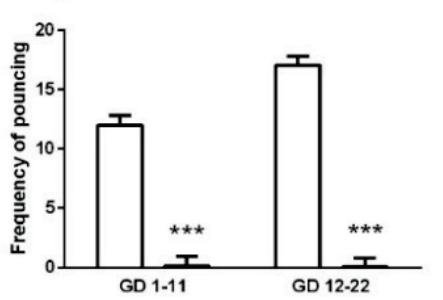

D)

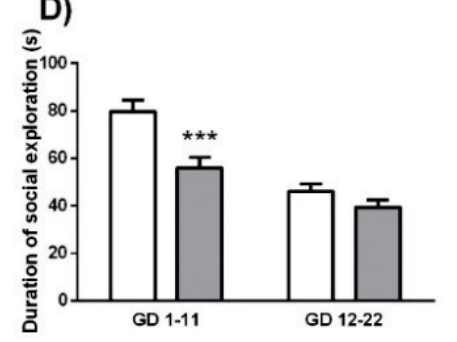

Fig. 3. Effect of acute MA exposure on social play behavior. (A) The frequency of pinning, (B) The frequency of pouncing, (C) Total play duration, (D) Duration of social exploration. Values are means \pm SEM $(n=32)$. Bars represent data regardless of sex and prenatal exposure period. The one-way ANOVA (acute drug) was used for statistical analyze. The main effect is given by asterisks: *** $\mathrm{p}<0.001$ acute MA vs. acute SA. Acute SA - acute saline exposure regardless of sex and prenatal drug exposure, Acute MA - acute methamphetamine exposure regardless of sex and prenatal drug exposure, GD gestational day.
There was a main effect of acute drug exposure: the one-way ANOVA (acute drug) showed that an acute dose of MA $(1 \mathrm{mg} / \mathrm{kg})$ eliminated social play behavior. Acute MA exposure decreased pinning in GD 1-11 exposure period $[\mathrm{F}(1,56)=71.37, \mathrm{p}<0.001]$, GD 12-22 exposure period $[F(1,56)=199.65, p<0.001]$ (Fig. 3A), pouncing in GD $1-11$ exposure period $[F(1,56)=109.28$, $\mathrm{p}<0.001]$, GD 12-22 exposure period $[\mathrm{F}(1,56)=249.43$, 
$\mathrm{p}<0.001$ ] (Fig. 3B), total play duration in GD 1-11 exposure period $[\mathrm{F}(1,56)=89.67, \mathrm{p}<0.001]$, GD 12-22 exposure period $[\mathrm{F}(1,56)=259.55, \mathrm{p}<0.001]$ (Fig. 3C). Social exploration was decreased by an acute dose of MA in the GD $1-11$ rats $[F(1,56)=13.14, p<0.001]$, but unchanged in the GD $12-22$ rats $[F(1,56)=2.41, p=0.13]$ (Fig. 3D).
A)

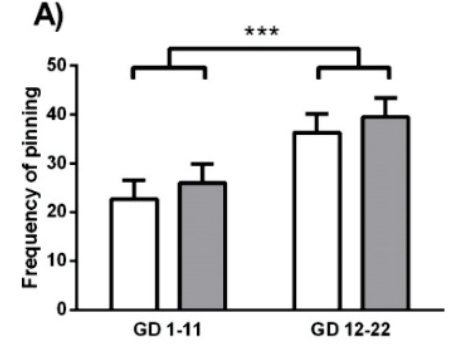

C)

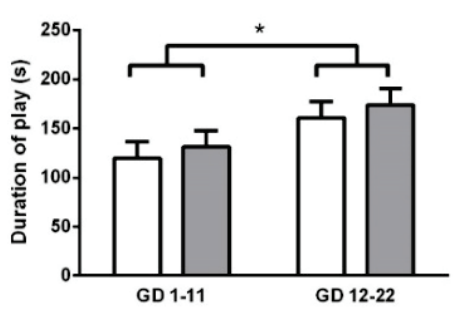

B)

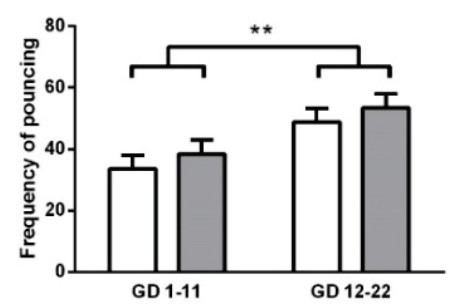

D)

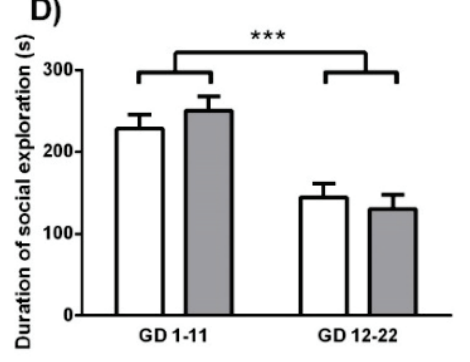

Fig. 4. Effect of prenatal exposure period on social play behavior. (A) The frequency of pinning, (B) The frequency of pouncing, (C) Total play duration, (D) Duration of social exploration. Values are means \pm SEM $(n=16)$. Bars represent data regardless of sex, groups with acute MA exposure were not used in the statistical evaluation. The one-way ANOVA (exposure period) was used for statistical analyze. The main effect is given by asterisks: $*$ $p<0.05$ exposure during GD 1-11 vs. GD 12-22 regardless the prenatal drug, $* * \mathrm{p}<0.01$ exposure during GD 1-11 vs. GD 12-22 regardless the drug, *** $\mathrm{p}<0.001$ exposure during GD 1-11 vs. GD 12-22 regardless the drug. SA - prenatal saline exposure, MA - prenatal methamphetamine exposure, GD - gestational day.
Effect of prenatal exposure periods on social play behavior

There was a main effect of prenatal exposure periods: application within GD 12-22 (regardless of the drug exposure) increased the rats pinned $[\mathrm{F}(1,60)=12.19$, $\mathrm{p}<0.001]$ (Fig. 4A) and pounced $[\mathrm{F}(1,60)=11.13, \mathrm{p}<0.01]$ (Fig. 4B) as well as total play duration $[\mathrm{F}(1,60)=6.46$, $\mathrm{p}<0.05$ ] (Fig. 4C) relative to exposure within GD 1-11 exposure period. On the other hand the social exploration was increased $[\mathrm{F}(1,60)=35.26, \mathrm{p}<0.001]$ in rats administered within GD 1-11 than GD 12-22 (Fig. 4D).

\section{Discussion}

Investigating the effects of drugs of abuse on social play behavior helps us to answer two questions. First, what are the neural substrates of social play behavior and second, how do drugs of abuse affect the development of social interactions prenatally and postnatally (Achterberg et al. 2014)? Therefore, the present study examined the effect of MA exposure during the first and second half of prenatal development relative to social play behavior and the acute effect of MA on social play behavior in adolescence. We expected that prenatal exposure to MA would cause changes in brain structures that are developing during the time of drug exposure, which would lead to corresponding functional changes. In addition, we expected more adverse MA exposure effects during GD 1-11 compared with GD 12-22 since GD 1-11 included the demanding processes of embryogenesis (Bayer et al. 1993).

We found that pouncing, pinning, and total play duration were increased after prenatal but not acute MA exposure in males of GD 1-11 exposure period, but only in the middle interval of the test. Prenatal MA GD 12-22 exposure did not produce any changes in social play elements or social exploration. Additionally, acute MA exposure eliminated social play behavior. Social exploration was decreased after acute MA exposure in GD 1-11 groups regardless of prenatal treatment. All social play behavior elements were decreased in the GD 1-11 rats compared with GD 12-22 rats irrespective of the prenatal drug (i.e., MA or SA).

The first goal of the present study was to examine the prenatal effect of MA on social play behavior. Deficits or decrease in social play behavior was expected. Surprisingly, social play elements and total play duration were increased in the middle interval of the test in males prenatally but not acutely exposed to MA, what is difficult to interpret. Since there is an absolute 
lack of studies examining prenatal MA or amphetamine effect on social play behavior, studies referring to the prenatal effect of cocaine might be explicatory. However, it should be mentioned that the mechanism of action of MA and cocaine is mediated through different neurotransmitters (Achterberg et al. 2014). In a study by Wood et al. (1994) social play behavior was decreased after prenatal cocaine exposure (GD 8-20). In the next study by these authors (Wood et al. 1995), pinning and pouncing were unaffected when the adolescent rats were exposed to a stressor (foot-shock, forces swim or white noise stress), suggesting that stress might have normalized play behavior in offspring prenatally exposed to cocaine. Neugebauer et al. (2004) reported that environmental manipulations weaken the effects of prenatal cocaine on social play behavior. While rearing in an impoverished environment increased play solicitation in rats prenatally exposed to cocaine, those raised in an enriched environment did not differ from controls. In a study by Magalhaes et al. (2006), play fighting, solicitation (pouncing) and social investigation were unaffected in offspring prenatally exposed to cocaine, when reared in a standard environment. However, rearing in an enriched environment decreased both play behavior and social investigation, explained that animals reared in an enriched environment prefer to explore a novel environment instead of engaging in social play (Sobrian and Holson 2011).

The second goal of this study was to investigate the acute effect of MA exposure, relative to social play behavior. Ours (Hrebíčková et al. 2017, Šlamberová et al. 2015a, Šlamberová et al. 2010) and other studies (Davidson et al. 2001, Syme and Syme 1974) demonstrated decreased social contact after acute MA exposure. Moreover, it has been shown that rats were still significantly less social several weeks after MA exposure than rats without MA exposure. On the SIT, prenatally MA-exposed males, when given an acute MA, amphetamine, and MDMA exposure, showed decreased time spent in social interactions compared with SA-exposed rats exposed in adulthood to the same drugs (Šlamberová et al. 2015b). Coming back to social play, it was shown that acute doses of cocaine, amphetamine, methylphenidate, and MDMA can all suppress social behavior at doses too low to induce psychomotor hyperactivity (Achterberg et al. 2014, Homberg et al. 2007, Vanderschuren et al. 2008). Our results are thus in line with other studies.

Social exploration is a standard parameter of anxiety used on the SIT (File and Seth 2003). It has been shown that playful social interactions are more rewarding than non-playful social interactions (Calcagnetti and Schechter 1992, Trezza et al. 2009b). In the present study, behaviors, which manifested interest in conspecific (e.g., sniffing, following, grooming) without elements of social play behavior (i.e., pouncing and pinning) was assigned as social exploration. Social exploration was decreased after acute MA exposure regardless of prenatal drug exposure in GD 1-11 rats, which is in agreement with our previous findings that social interactions in adult male rats decreased after acute exposure to MA, amphetamine, MDMA, and cocaine (Hrebíčková et al. 2017, Šlamberová et al. 2015a, Šlamberová et al. 2010). By contrast, neither prenatal nor acute exposure to MA produced any differences in groups prenatally exposed during GD 12-22. Moreover, no changes in social exploratory behavior and locomotor activity have been shown after the infusion of play-suppressors such as methylphenidate and atomoxetine into structures that are hypothesized to be the anatomical background of the emotional properties of social play, i.e., the anterior cingulate and infralimbic cortex, basolateral amygdala, and habenula (Achterberg et al. 2015).

In the present study, we have extended our previous findings from the SIT on adult rats. Nonetheless, social play behavior and social interaction in adult rats are regulated differently in the brain and may represent two different categories of behavior (Vanderschuren et al. 1995a, Vanderschuren et al. 1995b). Recently, the neurocircuitry of social play behavior that is affected by stimulants seems to have been revealed. It was demonstrated that amphetamine and methylphenidate inhibit social play via a noradrenergic mechanism of action. Their play-suppressant effect was imitated by the NA reuptake inhibitor atomoxetine, but not the DA reuptake inhibitor GBR12909, and their effect on social play was blocked by pretreatment with an antagonist of the $\alpha 2$-adrenoceptor, but not a DA receptor antagonist (Achterberg et al. 2014, Vanderschuren et al. 2008).

MA is one of the most frequently abused drugs by pregnant women (Marwick 2000). In an IDEAL (Infant Development, Environment, and Lifestyle) study, $84.3 \%$ of 191 drug-abusing mothers admitted using MA in the first, $56 \%$ in the second, and $42.4 \%$ in the third trimester. In addition, $29.3 \%$ of mothers sustained a high frequency, $9.4 \%$ increased their frequency, $25.7 \%$ had a steady use frequency, and $35.6 \%$ had a decreased frequency of MA abuse during their pregnancy (Della 
Grotta et al. 2010). Therefore, information regarding the consequences of MA abuse during different periods of pregnancy may influence addicted mothers to stop using MA on behalf of their unborn child. The third goal of our study was to compare the effect of prenatal MA exposure during the first and second half of the prenatal development. During early embryogenesis, drugs can have teratogenic outcomes or lead to malformations (Acuff-Smith et al. 1996, Davidson et al. 2001). On the other hand, drugs can have more subtle consequences during the late fetal development period, when the main processes of organogenesis are complete, e.g., changes in brain formation, volume of neurotransmitters, expression of receptors, and atypical growth (Acuff-Smith et al. 1996, Rice and Barone 2000). As predicted, the present results have confirmed decreased social play elements, i.e., pinning and pouncing, in prenatal GD 1-11 rats compared with GD 12-22 rats, which contradicts our previous study, using the SIT, and the same drug exposure schedule with adults. Specifically, adult MA GD 12-22 rats spent less time in mutual sniffing, climbing, crawling, and following compared with the MA GD 1-11 rats (Hrebíčková et al. 2017).

\section{Conclusion}

In conclusion, the present study leads us to question whether the timing of prenatal MA exposure is crucial relative to changes in postnatal development, emotional, and executive processes. To the best of our knowledge, this is the first study examining the prenatal effect of an amphetamine-type stimulant on social play behavior and offers two primary outcomes. First, our results suggest that manipulation during the first half of prenatal development creates more sensitivity to MA exposure and has a greater impact on social play behavior. Second, acute MA exposure can eliminate all social play behavior.

\section{Acknowledgment}

This study was supported by grant \# GA 18-03806S from the Grant Agency of the Czech Republic, project \# Progres Q35, GAUK 850317 and 260533/SVV/2020 from Charles University, Prague, and project PharmaBrain CZ.02.1.01/0.0/0.0/16_025/0007444 funded from OP VVV. The procedures for animal experimentation used in this study were approved by the Institutional Animal Care and Use Committee of Charles University and comply with the requirements of the Czech Government under the Policy of Humane Care of Laboratory Animals (No. 246/1992), with subsequent regulations from the Ministry of Agriculture of the Czech Republic (No. 311/1997). The authors express their appreciation to Zuzana Ježdíková, for her excellent technical assistance and Thomas Secrest, for critical reading and editing of the manuscript.

\section{References}

ACUFF-SMITH KD, GEORGE M, LORENS SA, VORHEES CV: Preliminary evidence for methamphetamineinduced behavioral and ocular effects in rat offspring following exposure during early organogenesis. Psychopharmacology (Berl) 109: 255-263, 1992. https://doi.org/10.1007/BF02245871

ACUFF-SMITH KD, SCHILLING MA, FISHER JE, VORHEES CV: Stage-specific effects of prenatal d-methamphetamine exposure on behavioral and eye development in rats. Neurotoxicol Teratol 18: 199-215, 1996. https://doi.org/10.1016/0892-0362(95)02015-2

ACHTERBERG EJ, TREZZA V, SIVIY SM, SCHRAMA L, SCHOFFELMEER AN, VANDERSCHUREN LJ: Amphetamine and cocaine suppress social play behavior in rats through distinct mechanisms. Psychopharmacology (Berl) 231: 1503-1515, 2014. https://doi.org/10.1007/s00213-013-3272-9

ACHTERBERG EJ, VAN KERKHOF LW, DAMSTEEGT R, TREZZA V, VANDERSCHUREN LJ: Methylphenidate and atomoxetine inhibit social play behavior through prefrontal and subcortical limbic mechanisms in rats. J Neurosci 35: 161-169, 2015. https://doi.org/10.1523/JNEUROSCI.2945-14.2015

BAYER SA, ALTMAN J, RUSSO RJ, ZHANG X: Timetables of neurogenesis in the human brain based on experimentally determined patterns in the rat. Neurotoxicology 14: 83-144, 1993.

CALCAGNETTI DJ, SCHECHTER MD: Place conditioning reveals the rewarding aspect of social interaction in juvenile rats. Physiol Behav 51: 667-672, 1992. https://doi.org/10.1016/0031-9384(92)90101-7 
DAVIDSON C, GOW AJ, LEE TH, ELLINWOOD EH: Methamphetamine neurotoxicity: necrotic and apoptotic mechanisms and relevance to human abuse and treatment. Brain Res Brain Res Rev 36: 1-22, 2001. https://doi.org/10.1016/S0165-0173(01)00054-6

DELLA GROTTA S, LAGASSE LL, ARRIA AM, DERAUF C, GRANT P, SMITH LM, SHAH R, HUESTIS M, LIU J, LESTER BM: Patterns of methamphetamine use during pregnancy: results from the Infant Development, Environment, and Lifestyle (IDEAL) Study. Matern Child Health J 14: 519-527, 2010. https://doi.org/10.1007/s10995-009-0491-0

DOUGLAS LA, VARLINSKAYA EI, SPEAR LP: Rewarding properties of social interactions in adolescent and adult male and female rats: impact of social versus isolate housing of subjects and partners. Dev Psychobiol 45 : 153-162, 2004. https://doi.org/10.1002/dev.20025

FILE SE, SETH P: A review of 25 years of the social interaction test. Eur J Pharmacol 463: 35-53, 2003. https://doi.org/10.1016/S0014-2999(03)01273-1

HERLENIUS E, LAGERCRANTZ H: Development of neurotransmitter systems during critical periods. Exp Neurol 190 Suppl 1: S8-21, 2004. https://doi.org/10.1016/j.expneurol.2004.03.027

HOLUBOVÁ A, ŠEVČÍKOVÁ M, MACÚCHOVÁ E, HREBÍČKOVÁ I, POMETLOVÁ M, ŠLAMBEROVÁ R: Effects of perinatal stress and drug abuse on maternal behavior and sensorimotor development of affected progeny. Physiol Res 66: S481-S491, 2017. https://doi.org/10.33549/physiolres.933800

HOMBERG JR, SCHIEPERS OJ, SCHOFFELMEER AN, CUPPEN E, VANDERSCHUREN LJ: Acute and constitutive increases in central serotonin levels reduce social play behaviour in peri-adolescent rats. Psychopharmacology (Berl) 195: 175-182, 2007. https://doi.org/10.1007/s00213-007-0895-8

HREBÍČKOVÁ I, MALINOVÁ-ŠEVČÍKOVÁ M, MACÚCHOVA E, NOHEJLOVÁ K, ŠLAMBEROVÁ R: Exposure to methamphetamine during first and second half of prenatal period and its consequences on cognition after long-term application in adulthood. Physiol Res 63 Suppl 4: S535-545, 2014.

HREBÍČKOVÁ I, ŠEVČÍKOVÁ M, MACÚCHOVÁ E, ŠLAMBEROVÁ R: How methamphetamine exposure during different neurodevelopmental stages affects social behavior of adult rats? Physiol Behav 179: 391-400, 2017. https://doi.org/10.1016/j.physbeh.2017.07.009

HREBÍČKOVÁ I, ŠEVČÍKOVÁ M, NOHEJLOVÁ K, ŠLAMBEROVÁ R: Does effect from developmental methamphetamine exposure on spatial learning and memory depend on stage of neuroontogeny? Physiol Res 65 (Suppl 5): S577-S589, 2016. https://doi.org/10.33549/physiolres.933534

JORDAN R: Social play and autistic spectrum disorders: a perspective on theory, implications and educational approaches. Autism 7: 347-360, 2003. https://doi.org/10.1177/1362361303007004002

KOLB B, MYCHASIUK R, MUHAMMAD A, LI Y, FROST DO, GIBB R: Experience and the developing prefrontal cortex. Proc Natl Acad Sci U S A 109 Suppl 2: 17186-17193, 2012. https://doi.org/10.1073/pnas.1121251109

MACÚCHOVÁ E, NOHEJLOVÁ K, ŠEVČÍKOVÁ M, HREBÍČKOVÁ I, ŠLAMBEROVÁ R: Sex differences in the strategies of spatial learning in prenatally-exposed rats treated with various drugs in adulthood. Behav Brain Res 327: 83-93, 2017. https://doi.org/10.1016/j.bbr.2017.03.041

MACÚCHOVÁ E, ŠEVČÍKOVÁ M, HREBÍČKOVÁ I, NOHEJLOVÁ K, ŠLAMBEROVÁ R: How various drugs affect anxiety-related behavior in male and female rats prenatally exposed to methamphetamine. Int $\mathrm{J}$ Dev Neurosci 51: 1-11, 2016. https://doi.org/10.1016/j.ijdevneu.2016.04.001

MACÚCHOVÁ E, ŠLAMBEROVÁ R: Does prenatal methamphetamine exposure induce sensitization to drugs in adulthood? Physiol Res 66: S457-S467, 2017. https://doi.org/10.33549/physiolres.933803

MAGAlHAES A, SUMMAVIELlE T, MELO P, ROSA R, TAVARES MA, DE SOUSA L: Prenatal exposure to cocaine and enriched environment: effects on social interactions. Ann N Y Acad Sci 1074: 620-631, 2006. https://doi.org/10.1196/annals.1369.060

MALINOVÁ-ŠEVČÍKOVÁ M, HREBÍČKOVÁ I, MACÚCHOVÁ E, NOVÁ E, POMETLOVÁ M, ŠLAMBEROVÁ $\mathrm{R}$ : Differences in maternal behavior and development of their pups depend on the time of methamphetamine exposure during gestation period. Physiol Res 63 Suppl 4: S559-572, 2014.

MARWICK C: NIDA seeking data on effect of fetal exposure to methamphetamine. JAMA 283: 2225-2226, 2000. https://doi.org/10.1001/jama.283.17.2225-JMN0503-2-1 
NEUGEBAUER NM, CUNNINGHAM ST, ZHU J, BRYANT RI, MIDDLETON LS, DWOSKIN LP: Effects of environmental enrichment on behavior and dopamine transporter function in medial prefrontal cortex in adult rats prenatally treated with cocaine. Brain Res Dev Brain Res 153: 213-223, 2004. https://doi.org/10.1016/j.devbrainres.2004.09.001

NIJHOF SL, VINKERS CH, VAN GEELEN SM, DUIJFF SN, ACHTERBERG EJM, VAN DER NET J, VELTKAMP RC, GROOTENHUIS MA, VAN DE PUTTE EM, HILLEGERS MHJ, VAN DER BRUG AW, WIERENGA CJ, BENDERS M, ENGELS R, VAN DER ENT CK, VANDERSCHUREN L, LESSCHER HMB: Healthy play, better coping: The importance of play for the development of children in health and disease. Neurosci Biobehav Rev 95: 421-429, 2018. https://doi.org/10.1016/j.neubiorev.2018.09.024

PANKSEPP J, SIVIY S, NORMANSELL L: The psychobiology of play: theoretical and methodological perspectives. Neurosci Biobehav Rev 8: 465-492, 1984. https://doi.org/10.1016/0149-7634(84)90005-8

PELLIS SM, PELLIS VC: Play fighting of rats in comparative perspective: a schema for neurobehavioral analyses. Neurosci Biobehav Rev 23: 87-101, 1998. https://doi.org/10.1016/S0149-7634(97)00071-7

RAMBOUSEK L, KAČER P, SYSLOVÁ K, BUMBA J, BUBENÍKOVÁ-VALEŠOVÁ V, ŠLAMBEROVÁ R: Sex differences in methamphetamine pharmacokinetics in adult rats and its transferal to pups via placental membrane and breast milk. Drug and Alcohol Dependence 139: 138-144, 2014. https://doi.org/10.1016/j.drugalcdep.2014.03.023

RICE D, BARONE S JR: Critical periods of vulnerability for the developing nervous system: evidence from humans and animal models. Environ Health Perspect 108 Suppl 3: 511-533, 2000. https://doi.org/10.1289/ehp.00108s3511

ROTHMAN RB, BAUMANN MH: Monoamine transporters and psychostimulant drugs. Eur J Pharmacol 479: 23-40, 2003. https://doi.org/10.1016/j.ejphar.2003.08.054

ROTHMAN RB, BAUMANN MH, DERSCH CM, ROMERO DV, RICE KC, CARROLL FI, PARTILLA JS: Amphetamine-type central nervous system stimulants release norepinephrine more potently than they release dopamine and serotonin. Synapse 39: 32-41, 2001. https://doi.org/10.1002/10982396(20010101)39:1<32::AID-SYN5>3.0.CO,2-3

RUBIN KH, WATSON KS, JAMBOR TW: Free-play behaviors in preschool and kindergarten children. Child Development 49: 534-536, 1978. https://doi.org/10.2307/1128725

RYAN AM, BERMAN RF, BAUMAN MD: Bridging the species gap in translational research for neurodevelopmental disorders. Neurobiol Learn Mem, 2018. https://doi.org/10.1016/j.nlm.2018.10.006

SCHMIDT RR, JOHNSON EM: Principles of teratology. Handbook of Developmental Toxicology. RD HOOD (ed). CRC Press, Boca Raton, FL., 1997, pp 3-12.

SCHUTOVÁ B, HRUBÁ L, POMETLOVÁ $M$, ROKYTA $R$, ŠLAMBEROVÁ R: Responsiveness to methamphetamine in adulthood is altered by prenatal exposure in rats. Physiol Behav 99: 381-387, 2010. https://doi.org/10.1016/j.physbeh.2009.12.004

SIVIY SM, PANKSEPP J: In search of the neurobiological substrates for social playfulness in mammalian brains. Neurosci Biobehav Rev 35: 1821-1830, 2011. https://doi.org/10.1016/j.neubiorev.2011.03.006

SOBRIAN SK, HOLSON RR: Social behavior of offspring following prenatal cocaine exposure in rodents: a comparison with prenatal alcohol. Front Psychiatry 2: 66, 2011. https://doi.org/10.3389/fpsyt.2011.00066

SULZER D, CHEN TK, LAU YY, KRISTENSEN H, RAYPORT S, EWING A: Amphetamine redistributes dopamine from synaptic vesicles to the cytosol and promotes reverse transport. J Neurosci 15: 4102-4108, 1995. https://doi.org/10.1523/JNEUROSCI.15-05-04102.1995

SUNDSTROM E, KOLARE S, SOUVERBIE F, SAMUELSSON EB, PSCHERA H, LUNELL NO, SEIGER A: Neurochemical differentiation of human bulbospinal monoaminergic neurons during the first trimester. Brain Res Dev Brain Res 75: 1-12, 1993. https://doi.org/10.1016/0165-3806(93)90059-J

SYME LA, SYME GJ: Group instability and the social response to methamphetamine. Pharmacol Biochem Behav 2: 851-854, 1974. https://doi.org/10.1016/0091-3057(74)90122-1

ŠEVČÍKOVÁ M, HREBÍČKOVÁ I, MACÚCHOVÁ E, ŠLAMBEROVÁ R: The influence of methamphetamine on maternal behavior and development of the pups during the neonatal period. Int J Dev Neurosci 59: 37-46, 2017. https://doi.org/10.1016/j.ijdevneu.2017.03.005 
ŠLAMBEROVÁ R, MIKULECKÁ A, MACÚCHOVÁ E, HREBÍČKOVÁ I, ŠEVČÍKOVÁ M, NOHEJLOVÁ K, POMETLOVÁ M: Effects of psychostimulants on social interaction in adult male rats. Behav Pharmacol 26: 776-785, 2015a. https://doi.org/10.1097/FBP.0000000000000148

ŠLAMBEROVÁ R, MIKULECKÁ A, POMETLOVÁ M, SCHUTOVÁ B, HRUBÁ L, DEYKUN K: The effect of methamphetamine on social interaction of adult male rats. Behav Brain Res 214: 423-427, 2010. https://doi.org/10.1016/j.bbr.2010.06.019

ŠLAMBEROVÁ R, POMETLOVÁ M, CHAROUSOVÁ P: Postnatal development of rat pups is altered by prenatal methamphetamine exposure. Prog Neuropsychopharmacol Biol Psychiatry 30: 82-88, 2006. https://doi.org/10.1016/j.pnpbp.2005.06.006

ŠLAMBEROVÁ R, POMETLOVÁ M, MACÚCHOVÁ E, NOHEJLOVÁ K, STUCHLÍK A, VALEŠ K: Do the effects of prenatal exposure and acute treatment of methamphetamine on anxiety vary depending on the animal model used? Behav Brain Res 292: 361-369, 2015b. https://doi.org/10.1016/j.bbr.2015.07.001

ŠLAMBEROVÁ R, POMETLOVÁ M, ROKYTA R: Effect of methamphetamine exposure during prenatal and preweaning periods lasts for generations in rats. Dev Psychobiol 49: 312-322, 2007. https://doi.org/10.1002/dev.20203

ŠLAMBEROVÁ R, VRAJOVÁ M, SCHUTOVÁ B, MERTLOVÁ M, MACÚCHOVÁ E, NOHEJLOVÁ K, HRUBÁ L, PUSKARČÍKOVÁ J, BUBENÍKOVÁ-VALEŠOVÁ V, YAMAMOTOVÁ A: Prenatal methamphetamine exposure induces long-lasting alterations in memory and development of NMDA receptors in the hippocampus. Physiol Res 63 Suppl 4: S547-558, 2014.

ŠPINKA M, NEWBERRY RC, BEKOFF M: Mammalian play: training for the unexpected. Q Rev Biol 76: 141-168, 2001. https://doi.org/10.1086/393866

TREZZA V, BAARENDSE PJ, VANDERSCHUREN LJ: Prosocial effects of nicotine and ethanol in adolescent rats through partially dissociable neurobehavioral mechanisms. Neuropsychopharmacology 34: 2560-2573, 2009a. https://doi.org/10.1038/npp.2009.85

TREZZA V, BAARENDSE PJ, VANDERSCHUREN LJ: The pleasures of play: pharmacological insights into social reward mechanisms. Trends Pharmacol Sci 31: 463-469, 2010. https://doi.org/10.1016/j.tips.2010.06.008

TREZZA V, DAMSTEEGT R, VANDERSCHUREN LJ: Conditioned place preference induced by social play behavior: parametrics, extinction, reinstatement and disruption by methylphenidate. Eur Neuropsychopharmacol 19: 659-669, 2009b. https://doi.org/10.1016/j.euroneuro.2009.03.006

VAN DEN BERG CL, HOL T, VAN REE JM, SPRUIJT BM, EVERTS H, KOOLHAAS JM: Play is indispensable for an adequate development of coping with social challenges in the rat. Dev Psychobiol 34: 129-138, 1999. https://doi.org/10.1002/(SICI)1098-2302(199903)34:2<129::AID-DEV6>3.0.CO,2-L

VANDERSCHUREN LJ, ACHTERBERG EJ, TREZZA V: The neurobiology of social play and its rewarding value in rats. Neurosci Biobehav Rev 70: 86-105, 2016. https://doi.org/10.1016/j.neubiorev.2016.07.025

VANDERSCHUREN LJ, NIESINK RJ, VAN REE JM: The neurobiology of social play behavior in rats. Neurosci Biobehav Rev 21: 309-326, 1997. https://doi.org/10.1016/S0149-7634(96)00020-6

VANDERSCHUREN LJ, STEIN EA, WIEGANT VM, VAN REE JM: Social isolation and social interaction alter regional brain opioid receptor binding in rats. Eur Neuropsychopharmacol 5: 119-127, 1995a. https://doi.org/10.1016/0924-977X(95)00010-M

VANDERSCHUREN LJ, STEIN EA, WIEGANT VM, VAN REE JM: Social play alters regional brain opioid receptor binding in juvenile rats. Brain Res 680: 148-156, 1995b. https://doi.org/10.1016/0006-8993(95)00256-P

VANDERSCHUREN LJ, TREZZA V: What the laboratory rat has taught us about social play behavior: role in behavioral development and neural mechanisms. Curr Top Behav Neurosci 16: 189-212, 2014. https://doi.org/10.1007/978-3-662-45758-0_268

VANDERSCHUREN LJ, TREZZA V, GRIFFIOEN-ROOSE S, SCHIEPERS OJ, VAN LEEUWEN N, DE VRIES TJ, SCHOFFELMEER AN: Methylphenidate disrupts social play behavior in adolescent rats. Neuropsychopharmacology 33: 2946-2956, 2008. https://doi.org/10.1038/npp.2008.10

WOOD RD, BANNOURA MD, JOHANSON IB: Prenatal cocaine exposure: effects on play behavior in the juvenile rat. Neurotoxicol Teratol 16: 139-144, 1994. https://doi.org/10.1016/0892-0362(94)90110-4 
WOOD RD, MOLINA VA, WAGNER JM, SPEAR LP: Play behavior and stress responsivity in periadolescent offspring exposed prenatally to cocaine. Pharmacol Biochem Behav 52: 367-374, 1995. https://doi.org/10.1016/0091-3057(95)00120-L

YAMAMOTOVÁ A, HRUBÁ L, SCHUTOVÁ B, ROKYTA R, ŠLAMBEROVÁ R: Perinatal effect of methamphetamine on nociception in adult Wistar rats. Int J Dev Neurosci 29: 85-92, 2011. https://doi.org/10.1016/j.ijdevneu.2010.08.004 